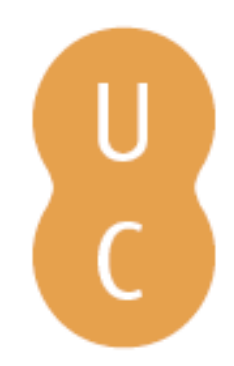

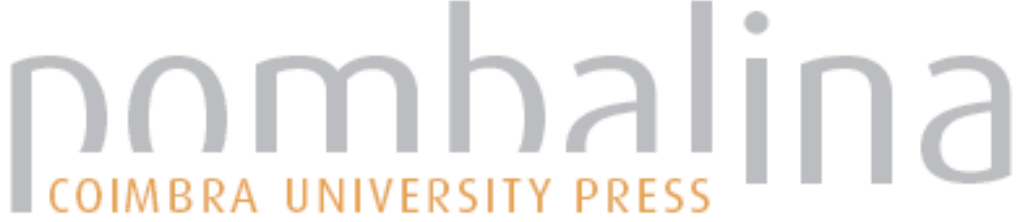

\section{Residents' experiences of the 2016 Fort McMurray Wildfire, Alberta}

\author{
Autor(es): $\quad$ McGee, Tara K.
}

Publicado por: Imprensa da Universidade de Coimbra

URL

persistente: URI:http://hdl.handle.net/10316.2/44646

DOI: $\quad$ DOI:https://doi.org/10.14195/978-989-26-16-506_129

Accessed : $\quad$ 26-Apr-2023 12:59:18

A navegação consulta e descarregamento dos títulos inseridos nas Bibliotecas Digitais UC Digitalis, UC Pombalina e UC Impactum, pressupõem a aceitação plena e sem reservas dos Termos e Condições de Uso destas Bibliotecas Digitais, disponíveis em https://digitalis.uc.pt/pt-pt/termos.

Conforme exposto nos referidos Termos e Condições de Uso, o descarregamento de títulos de acesso restrito requer uma licença válida de autorização devendo o utilizador aceder ao(s) documento(s) a partir de um endereço de IP da instituição detentora da supramencionada licença.

Ao utilizador é apenas permitido o descarregamento para uso pessoal, pelo que o emprego do(s) título(s) descarregado(s) para outro fim, designadamente comercial, carece de autorização do respetivo autor ou editor da obra.

Na medida em que todas as obras da UC Digitalis se encontram protegidas pelo Código do Direito de Autor e Direitos Conexos e demais legislação aplicável, toda a cópia, parcial ou total, deste documento, nos casos em que é legalmente admitida, deverá conter ou fazer-se acompanhar por este aviso.

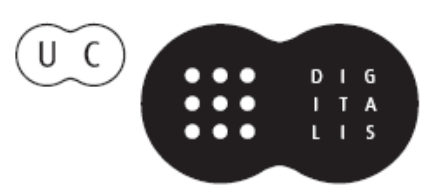




\section{ADVANCES IN}

\section{FOREST FIRE RESEARCH}

\section{8}

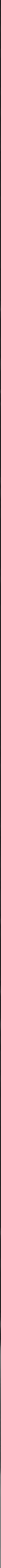




\title{
Residents' experiences of the 2016 Fort McMurray Wildfire, Alberta
}

\author{
Tara K. McGee \\ University of Alberta. c/o 1-26 Earth Sciences Building, University of Alberta, Edmonton, Alberta, \\ Canada, \{tmcgee@ualberta.ca\}
}

\begin{abstract}
In May 2016, the urban centre of Fort McMurray in Alberta, Canada, was devastated by the Horse River wildfire (known as the Fort McMurray wildfire), which destroyed 2400 homes and caused the evacuation of 88,000 residents. I will present results from two online surveys carried out with a sample of residents who evacuated during the wildfire. The first survey, administered one month after the fire in June 2016, was designed to explore residents' initial evacuation experiences. The survey was developed using SurveyMonkey and distributed through Facebook groups devoted to the wildfire evacuation, Twitter, two First Nations and one First Nation organization. 447 residents of the Regional Municipality of Wood Buffalo (RMWB) completed the survey. Before the wildire occurred on May 1st, many survey respondents were unaware of the wildfire risk. On May 3rd, many respondents left their home or workplace at the last minute with little if any warning, and many experienced difficulties leaving their neighbourhood and Fort McMurray. Once they left Fort McMurray, evacuees who responded to the survey stayed in many towns throughout Alberta, Canada, and some returned home to international destinations. Social media served as a very important source of information for survey respondents. An enormous outpouring of support was provided to evacuees during and following the wildfire. Some evacuees were allowed to return to Fort McMurray starting at the beginning of June 2016, while others were unable to return until later in the summer. A second survey was administered in March 2018 to examine residents' decisions about when to return to Fort McMurray, challenges faced during the initial re-entry process and later in the recovery, and support received by residents. Lasting impacts of the wildfire on survey respondents are also identified.
\end{abstract}

Keywords: Experiences, wildfire evacuation, recovery

\section{Introduction}

Evacuations are used by governments in many countries to protect public safety in the event of a wildfire and other hazards. For example, between 1980 and 2007, there were 547 wildfire evacuations in Canada, resulting in the evacuation of an average of 7469 people per year (Beverly and Bothwell 2011). Evacuations may be voluntary where residents can choose whether to evacuate, or mandatory where residents are obliged to leave. Researchers have found that wildfire evacuations can cause considerable stress and anxiety for evacuees due to disruption in daily routines, loss of control, uncertainty about personal safety and the safety of their homes, and proximity of danger (Kent et al 2003; Cohn et al 2006; Afifi et al 2012). Evacuees with low levels of social support suffer more mental health issues than those with average or high levels of social support (Felix and Afifi 2015). However there is also some evidence that evacuations may have positive impacts when the residents become closer during the experience (Kent et al 2003).

On May 1st, 2016, the Horse River Fire started in the Regional Municipality of Wood Buffalo and quickly grew in size due to extremely hot and dry conditions. At 8pm, the RMWB's emergency department warned people in Centennial trailer park in the south of Fort McMurray to leave their homes, and put the neighbourhoods of Beacon Hill and Gregoire on evacuation alert. At 10pm, a state of local emergency was declared and a mandatory evacuation was ordered for residents of Centennial RV Park Campground, Prairie Creek and Gregoire. On Monday May 2nd, the fire grew and was almost $1 \mathrm{~km}$ from Highway 63, the road in and out of Fort McMurray. Overnight, the fire expanded west, away from the city. 
On the morning of Wednesday May 3rd, the smoke and flames were not visible from the city, but at $11 \mathrm{am}$ the fire chief warned that winds could shift. At noon, the fire jumped the Athabasca River and headed towards the city. Later that day, the Horse River wildfire entered Fort McMurray. The neighbourhoods of Beacon Hill, Abasand and the MacKenzie Industrial Park were impacted first. Although some residents had already evacuated, a mandatory evacuation order was issued by the RMWB for all of Fort McMurray at 16:20. Later in the evening, the wildfire entered the subdivisions of Thickwood and Waterways (MNP 2017).

People in the neighbourhoods of Waterways, Beacon Hill, and Abasand south of the Athabasca River were told to evacuate and head south on Highway 63. Due to traffic impediments as people in the Abasand, Beacon Hill and waterways were leaving and taking Highway 63 south, residents in neighbourhoods north of the Athabasca River were told to leave and go north on Highway 63. The estimated 15,000 to 20,000 evacuees who headed north stayed in work camps and Fort McKay First Nation. On May 4th, the province of Alberta declared a state of emergency and called for a mandatory evacuation of Saprae Creek at 4pm. At 10pm, a mandatory evacuation was ordered by the provincial government for Anzac, Gregoire Lake Estates, and Fort McMurray First Nation. A few days after May 3rd, the fire started heading north and supplies started to run out in the work camps, so evacuees were either flown out to Calgary or Edmonton, or drove south on Highway 63 back through Fort McMurray to stay elsewhere.

The Horse River fire destroyed 2400 homes and caused the evacuation of more than 88,000 residents, the largest wildfire evacuation in Canadian history. The fire was under control on July 4th after it has burned 589,552 hectares. The government of Alberta completed a phased re-entry process which allowed the first residents to return to RMWB on June 1st. Government responses to this wildfire have been examined in studies completed following the wildfire (KPMG 2017a, b; MNP 2017). These studies that examine how local and provincial government agencies responded to the wildfire provide important insights into the wildfire response. However, further study is needed to examine the experiences of residents who fled from their homes and neighbourhoods during this wildfire.

I will present the results of two online surveys completed with residents of RMWB who evacuated due to the May 2016 wildfire. The first survey was administered in June 2016, and was designed to explore residents' evacuation experiences from when the fire started, leaving, staying elsewhere during the evacution, and what helped and hindered the evacuation from their perspectives. The second survey was administered in March 2018 nearly two years after the wildfire, to examine residents' decisions about when to return to Fort McMurray, challenges faced during the initial re-entry process and later in the recovery, and support received by residents. Lasting impacts of the wildfire on survey respondents are also identified.

\section{Methods}

The first phase of this research project was initially conceived in May 2016 immediately after the wildfire evacuation of RMWB. The online survey method was selected to ensure that I could reach residents who were staying in a variety of places during the evacuation to learn about a variety of experiences. In addition, a very large and active Facebook Group that was set up at the time of the fire, 'Fort McMurray Evac Relocation Group', provided a way to reach evacuees using an online survey. The benefits of online surveys (Evans and Mathur 2018) were also important considerations. Use of SurveyMonkey provided flexibility in the question types, format, and response options, and convenience for participants; and the data analysis tools offered by SurveyMonkey also enabled data analysis to be completed fairly quickly. A short online survey was also appropriate for people who were very busy trying to cope during and shortly after the wildfire. 
This research was approved by the University of Alberta human research ethics board 1 . The survey administered in June 2016 was designed to learn about residents' initial evacuation experiences in the early days after the wildfire. The survey was developed by the author and a research assistant using SurveyMonkey. The survey included closed-ended and open-ended questions, and was designed to be completed within 10 minutes. A purposive sampling strategy was used to recruit survey participants. After obtaining ethics clearance, the survey was posted online on June 21, 2016. RMWB residents who had evacuated due to wildfire in May were invited to participate through invitations posted in Facebook groups devoted to the wildfire evacuation, Twitter, and by emailing information about the survey to two First Nations and one First Nation organization. 447 residents of the Regional Municipality of Wood Buffalo completed this online survey. The results of this first survey were analyzed using SurveyMonkey's data analysis capabilities.

In March 2016, I developed a follow-up survey to examine residents' decisions about when to return to Fort McMurray, challenges faced during the initial re-entry process and later in the recovery, and support received by residents. Lasting impacts of the wildfire on survey respondents two months short of the 2-year anniversary of the fire are also identified. Similar to the first survey, this second survey included both closed-ended and open-ended questions and was designed to be completed within 10 minutes. I recruited participants for the follow-up survey by emailing a link to the survey to 120 participants in the 2016 survey who indicated they would be interested in participating in further research. $62(51.6 \%)$ of these 120 residents completed the follow-up survey. The results of this followup survey were also analyzed using SurveyMonkey's data analysis capabilities.

\section{Findings}

\subsection{June 2016 Survey}

Survey respondents included those with a range of characteristics. Most survey respondents $(93.8 \%)$ were living in Fort McMurray before the fire, with the remaining 24 respondents living in other communities in the RMWB. Survey participants included those in a range of age groups, with $3.9 \%$ 18-24 years of age, $25.5 \%$ 25-34, 29.0\% 35-44, 25.5\% 45-54, 13.1\% 55-64, 2.1\% 65-74, and $2.1 \%$ age 75 and over. Most survey respondents $(81.2 \%)$ were women, $16.7 \%$ men, and $0.26 \%$ other. $63.5 \%$ of respondents stated that they were in full time paid employment before the wildfire, $8.5 \%$ had full time domestic/parenting duties, $8 \%$ were unemployed, $8 \%$ had part-time/casual employment, $7.7 \%$ were unemployed, $4.9 \%$ retired, and $1.8 \%$ full time students. Most survey respondents' homes had minor damage $(40.9 \%)$ or no damage at all $(35.7 \%)$, but $17.7 \%$ of respondents had lost their home in the wildfire.

A few days before the evacuation, most respondents perceived the wildfire threat to be low. This is surprising due to Fort McMurray's location in the boreal forest, past wildfires in the area, and hot and dry conditions in the weeks before the wildfire. The Residents became aware of the Horse River wildfire entering Fort McMurray and the need to evacuate because of what they could see (19.9\%), from information on the radio $(19.4 \%)$, and from a family member $(15.3 \%)$. Others learned they would have to leave from a posting on social media (9.8\%), their employer (9.1\%), a friend or neighbour $(7.9 \%)$, with a few receiving this information from an RCMP officer, TV, or from the RMWB website. Many had little or no time to prepare to leave. $11.7 \%$ had to leave immediately and did not have any time to get ready, $16.9 \%$ spent less than 15 mintes getting ready, while another $39.1 \%$ said that they spent between 15 minutes and 1 hour getting ready. $16.6 \%$ spent between 1 and 2 hours getting ready to leave, and only $8.6 \%$ said that they spent more than 2 hours getting ready. As survey respondents tried to leave their neighbourhoods and urban Fort McMurray, 52.7\% stated that they experienced difficulties. Traffic delays were common for residents trying to leave their neighbourhood and then once they were heading north or south on Highway 63. Many survey respondents ran out of gas. Some respondents said they were not sure which way to go on Highway 63. Some survey respondents were 
separated from family members and friends during their departure. Others did not have enough food or water during the drive away from Wood Buffalo. Many survey respondents also spoke of the fear they experienced as they were trying to leave while the fire was burning around them.

Evacuees stayed in many towns throughout Alberta, elsewhere in Canada, and some returned home to international destinations during the evacuation. A majority of survey respondents stayed in more than one community, which caused additional challenges. Social media served as a very important source of information for survey respondents, but $46.1 \%$ of survey respondents stated that they did not receive enough information during the evacuation. An enormous outpouring of support was provided to evacuees during and following the wildfire from local residents, elsewhere in the province of Alberta, Canada, and overseas. Evacuees received help from a vast array of sources including friends, family, strangers, aid organizations, the government of Alberta, host communities, and businesses. Financial support from the Government of Alberta and the Red Cross, and donations from other organizations were appreciated by survey respondents, however some survey respondents experienced challenges accessing funds from the Red Cross.

Some evacuees were allowed to return to Fort McMurray starting at the beginning of June 2016, while others were unable to return until later in the summer.

\subsection{March 2018 Survey}

These survey respondents had varied home loss experiences, with $21.05 \%$ losing their home, $5.25 \%$ whose home had major damage, $36.84 \%$ experiencing minor damage to their home, and $36.84 \%$ whose home was not damaged due to the wildfire. $94.74 \%$ of survey respondents stated that they had insurance for their home at the time of the wildfire. At the time of the survey, $59.65 \%$ of respondents were living in the home where they lived before the Fort McMurray wildfire, $7.02 \%$ were living in temporary accommodation until they can rebuild their home, $12.28 \%$ were living in a different home, and $21.05 \%$ were living elsewhere including a newly built home or in a house in another city where they now reside.

Most (88.5\%) of the 62 follow-up survey respondents had returned to live in the RMWB since the wildfire, but $11.48 \%$ (7) had not returned. Most survey respondents (78.18\%) returned to RMWB for the first time to their home or property after the wildfire in June, with $20 \%$ returning in July or August. Most survey respondents also returned to live permanently in RMWB in June (64.81\%), with 29.63\% returning to live permanently in July or August. A majority of survey participants (58.49\%) indicated that they were concerned about returning to live permanently in the RMWB after the wildfire, with $41.51 \%$ indicating they were not concerned. Most participants (83.3\%) faced challenges during the reentry phase. Most respondents (76.67\%) said they received help during this phase from friends and family, the Red Cross and counselling services, re-entry centres, and appreciated the welcome back from first responders and support from strangers.

After the re-entry phase, survey respondents dealt with insurance; fixed damaged homes and replaced lost furniture, apliances, and belongings; and dealt with the social and psychological impacts of the wildfire. During this stage of the recovery process, $70.37 \%$ experienced challenges related to the insurance and restoration companies, the rebuilding process, mental health impacts, and financial losses. Help received during this part of the recovery process came from friends and family, coworkers, other residents of RMWB, the Red Cross, counsellors, and the municipality, and Facebook groups. Twenty-three participants expressed that their experiences with the wildfire re-entry and recovery had lasting impacts on them or their household members, from a heightened appreciation of what they have and empathy for others going through a difficult time, to ongoing mental health impacts. As several participants explained, it was a life-altering event.

\section{Conclusions}

The results of this study highlight what can happen when a sizeable population has to evacuate at the last minute due to a wildfire. Limited road access out of neighbourhoods and away from Fort 
McMurray caused traffic delays, which resulted in residents running out of gas and in some cases food and water as they tried to get to safety. The need to evacute quickly also meant that there was some confusion about how to get out of Fort McMurray safely, and separation of families and friends also occurred. It is clear that this last minute evacuation contributed to the trauma experienced by survey respondents.

The recovery process as experienced by survey respondents in Fort McMurray follows the key steps in the disaster recovery process as identified in the SAMHSA phases of disaster collective reactions model: the heroic phase and honeymoon state, where Fort McMurray residents helped each other and were helped by others, particularly while residents were away from Fort McMurray. Importantly, the SAMHSA model indicates that the disillusionment phase occurs up to one year, then after the 1-year anniversary, residents work through their grief. The results of the follow-up survey clearly show that some survey respondents are still in the disillusionment phase, with some still waiting to rebuild their house and dealing with the mental health impacts of the wildfire.

The results of this provide important insights into the wildfire evacuation and recovery process at two points in time: 1 month after the wildfire and 22 months afterwards. The timing of the first survey enabled the collection of recent experiences which were still vivid in survey respondents' memories. The second survey followed the same respondents to learn about their experienes in the recovery process almost 2 years after the wildfire. Further follow-up study is planned to examine the recovery process as it continues over the next few years.

\section{References}

Afifi WA, Felix ED, Afifi TD (2012) The impact of uncertainty and communal coping on mental health following natural disasters. Anxiety, Stress, \& Coping: An International Journal 25(3): 329347. Doi: 10.1080/10615806.2011.603048

Beverly JL, Bothwell P (2011) Wildfire evacuations in Canada 1980 - 2007. Natural Hazards, 59(1), 571-596.

Cohn PJ, Carroll MS, Kumagai Y (2006) Evacuation behaviour during wildfires: results of three case studies. West J. Appl. For. 21(1): 39-48.

Evans JR, Mathur A (2018) The value of online surveys: a look back and a look ahead. Internet Research, https://doi.org/10.1108/IntR-03-2018-0089

Felix ED, Afifi W (2015) The role of social support on mental health after multiple wildfire disasters. J Community Psychol 43(2),156-170.

Kent B, Gebert K, McCaffrey S, Martin W, Calkin D, Schuster E, Martin I, Bender HW, Alward G, Kumagai Y, Cohn PJ, Carroll MS, Williams D, Ekarius C (2003) Social and economic issues of the Hayman fire. USDA, Forest Service Rocky Mountain Research Station, Fort Collins, Colorado. Pp. 315-396. Gen Tech Rep RMRS-GTR-114.

KPMG (2017a) Regional Municipality of Wood Buffalo Lessons Learned and Recommendations from the 2016 Horse River Wildfire. July 27, 2017, Final Report.

KPMG (2017b) May 2016 Wood Buffalo Wildfire Post-Incident Assessment Report. Prepared for Alberta Emergency Management Agency, May 2017, Final Report.

MNP (2017) A Review of the 2016 Horse River Wildfire Alberta Agriculture and Forestry Preparedness and Response.

SAMHSA (undated) Phases of Disaster. https://www.samhsa.gov/programscampaigns/dtac/recovering-disasters/phases-disaster 